\title{
Factors influencing the cultivability of lake water bacteria
}

\author{
Ingeborg Bussmann ${ }^{\mathrm{a}, *}$, Bodo Philipp ${ }^{\mathrm{b}}$, Bernhard Schink ${ }^{\mathrm{a}}$ \\ ${ }^{a}$ LS Mikrobielle Ökologie, Fachbereich Biologie, Universität Konstanz, P.O. Box 5560, D-78457 Konstanz, Germany \\ ${ }^{\mathrm{b}}$ Institute of Pharmaceutical Sciences, University of Nottingham, Nottingham, UK
}

Received 24 March 2001; received in revised form 17 May 2001; accepted 17 May 2001

\begin{abstract}
Counting bacteria in natural water samples by cultivation yields only low recovery efficiencies (ca. 1\%), compared to total counts obtained after 4,6-diamidino-2-phenylindol (DAPI) staining. In order to optimize the cultivation of heterotrophic planktonic bacteria from Lake Constance (Germany), selected parameters of the medium composition were modified. The most important factor was the concentration of organic substrate (nutrient broth plus yeast extract), which significantly influenced the "most probable number" obtained in liquid growth medium. Reduced oxygen concentrations $(3-12 \%)$ lowered the "most probable number". Addition of $\mathrm{N}$-acyl homoserine lactones to the medium increased the cultivability slightly. Low substrate concentrations $[0.03-0.06 \%(\mathrm{w} / \mathrm{v})]$, an incubation atmosphere of $21 \%$ oxygen at $16{ }^{\circ} \mathrm{C}$ for 4 weeks were optimal and increased the cultivability ("most probable number" related to total bacterial counts) to an average cultivability of $18 \pm 11 \%,(n=8)$. The results indicate that cultivabilities of heterotrophic bacteria from lakewater samples can be significantly increased by modifying the cultivation methods.
\end{abstract}

Keywords: Counting efficiency; Heterotrophic aerobes; Lake Constance; $N$-acyl homoserine lactones; Oxygen stress; Planktonic bacteria

\section{Introduction}

Only a minor percentage of the total number of bacteria in a natural water sample can be cultivated by conventional techniques. The cultivability of bacteria from different habitats ranges from $0.25 \%$ in freshwater to up to $2 \%$ in seawater (Amann et al., 1995; Bernard et al., 2000). Total bacterial counts

\footnotetext{
* Corresponding author. Tel.: +49-7531-882973; fax: +497531-882966.

E-mail address: ingeborg.bussmann@uni-konstanz.de (I. Bussmann).
}

(TBC), i.e. $100 \%$, are determined by counting bacteria-like particles stained with different dyes, such as acridine orange, 4,6-diamidino-2-phenylindol (DAPI) or Sybr Green (Turley, 1993; Weinbauer et al., 1998). Viable counts of aerobic heterotrophic bacteria are obtained from plate counts or with the "most probable number" (MPN) technique in liquid medium, of which the latter one usually yields higher cell counts (Reichardt, 1978). Complex organic substrates have been used successfully for growth of a high fraction of bacterial cells and for isolation of numerically dominant bacterial strains from various aquatic environments (Pinhassi et al., 1997). While conventional culture techniques underestimate the number of truly viable bacteria, counting all bacteria-like particles overestimates the TBC, be- 
cause it includes also dead bacteria and non-living bacteria-like particles (Catala et al., 1999). In order to overcome this discrepancy, new dyes were developed to stain nucleic acids more specifically, and to distinguish between "living" and "dead" bacteria by differentiating specifically between cells with and without membrane potential as a marker of active metabolism (Catala et al., 1999). On the other hand, molecular probes for in situ hybridisation to $16 \mathrm{~S}$ rRNA were applied, and counts up to $50 \%$ of the TBC were obtained (Pernthaler et al., 1998).

In context with pathogenic bacteria, the expression of "viable but non-culturable" bacteria has been coined (McDougald et al., 1998). By now, there is little doubt that most of the non-culturable bacteria are viable, but do not exhibit detectable growth, mostly due to non-suited cultivation media (Amann et al., 1995). However, only little effort has been made to improve the media used to cultivate aerobic bacteria from natural water samples. Although no single medium can be expected to support growth of all bacteria in a mixed community, it should be possible to improve our techniques to cultivate aquatic bacteria by developing media that better reflect the conditions of microbial life in the environments sampled. Beyond minimising the gap between viable and total bacterial counts, cultivating more bacteria also implies the possibility of cultivating new, so far not cultured bacteria. The physiology and ecological role of these unknown bacterial species can only be assessed after growing them in the laboratory.

In the present study, we modified various cultivation parameters in order to find a combination which yielded significantly higher viable counts than obtained so far with conventional cultivation media.

\section{Methods}

Lake Constance is a warm-monomictic, large (surface area $539 \mathrm{~km}^{2}$ ) and deep (mean depth $=100$ m) prealpine lake. After a period of eutrophication, concentrations of inorganic nutrients and dissolved organic carbon decreased $\left(0.3 \mu \mathrm{M} \mathrm{PO} \mathrm{PO}_{4} ; 70 \mu \mathrm{M}\right.$ $\mathrm{NO}_{3} ; 1-2 \mathrm{mg}^{-1}$ DOC) (Stabel, 1998), and today, the lake is described again as oligotrophic. There are several studies on the dynamics and nutrient utilization patterns of the bacterioplankton in Lake Constance (Weiss and Simon, 1999), but no recent publication deals with the cultivation of this plankton community.

Samples were taken between March 1999 and August 2000 from surface water $(\mathrm{ca} .10 \mathrm{~cm}$ ) at the pier of the Limnological Institute, Konstanz-Egg, approximately $20 \mathrm{~m}$ from the shore. Samples were kept cold $\left(4{ }^{\circ} \mathrm{C}\right)$ and processed in the laboratory within $6 \mathrm{~h}$.

The "most probable number" technique was used to enumerate heterotrophic, planktonic bacteria. Dilution series were prepared with filter-sterilized lake water. Before each transfer and before inoculating the microtiter plates, samples were mixed vigorously for $1 \mathrm{~min}$ on a Vortex mixer to disintegrate possible aggregates. Cultures were incubated in sterile microtiter plates (Nuclon), with 12 dilution steps and 8 parallels in one plate. Wells containing non-inoculated medium served as control for possible crosscontamination.

The basic mineral medium with low concentrations of inorganic nutrients contained per litre: $\mathrm{NaCl}$ $1.0 \mathrm{~g} ; \mathrm{MgCl}_{2} \cdot 6 \mathrm{H}_{2} \mathrm{O} 0.4 \mathrm{~g} ; \mathrm{KNO}_{3} 0.05 \mathrm{~g} ; \mathrm{KCl} 0.5$ $\mathrm{g} ; \mathrm{CaCl}_{2} \cdot 2 \mathrm{H}_{2} \mathrm{O} 0.15 \mathrm{~g} ; \mathrm{Na}_{2} \mathrm{SO}_{4} 0.16 \mathrm{~g}$, and $1 \mathrm{ml}$ trace element solution SL 10 (Widdel et al., 1983). Phosphate was added after autoclaving from a $1 \mathrm{M}$ stock solution $\left(0.5 \mathrm{M} \mathrm{KH}_{2} \mathrm{PO}_{4} / 0.5 \mathrm{M} \mathrm{Na}_{2} \mathrm{HPO}_{4}\right)$ to a final concentration of $150 \mu \mathrm{M}$. The medium was buffered with $0.01 \mathrm{M} \mathrm{N}$-2-hydroxyethylpiperazine$N^{\prime}$-2-ethanesulfonic acid (HEPES, Sigma) to $\mathrm{pH}$ 7.2.

Inoculated plates were incubated at $16{ }^{\circ} \mathrm{C}$ in the dark. Turbidity was measured with an Anthos ht II photometer at 595-nm wavelength. For MPN evaluation, a well was scored positive if its turbidity was more than $150 \%$ of the average control value. Stable MPN values were recorded after 4 weeks of incubation.

Additionally, positive scores were verified by protein assays (Pierce BCA $^{*}$ Protein Assay kit, enhanced protocol, Pierce Chemical, USA). Six wells were pooled, centrifuged, and the pellet was extracted with $1 \mathrm{M} \mathrm{NaOH}$. The lower detection limit was $0.01 \mathrm{mg} \mathrm{ml} \mathrm{m}^{-1}$, with bovine serum albumin (Sigma) as standard.

MPN values with standard error and 95\% confidence intervals were calculated with a computer 
program by J.D. Hoolwerf, according to Russek and Colwell (1983). MPN values with a non-overlapping 95\% confidence interval were considered significantly different with $p<0.05$. Further statistical analysis was done with StatView 4.5 for Macintosh.

\subsection{Influence of substrate concentration}

The influence of the organic substrate concentration was tested several times during 1999 and 2000. In most experiments $(n=7)$, the organic substrate content ranged from $0.06 \%$ to $0.3 \%, 0.6 \%$ and $3 \%$ $\mathrm{w} / \mathrm{v}$. Filter-sterilized nutrient broth plus yeast extract $(5 / 6+1 / 6, \mathrm{w} / \mathrm{v}$, Difco) served as substrate. In additional experiments $(n=5)$, substrate concentrations were lowered to $0.03 \%$ and $0.006 \%$, and at two sampling dates, also to $0.003 \%, 0.0006 \%$ and $0.0003 \%(\mathrm{w} / \mathrm{v})$. To increase sensitivity of growth detection at these low substrate concentrations, incubation time was extended to 8 weeks and turbidity was measured every 2 weeks. Wells were scored positive if the turbidity increased steadily over time.

\subsection{Influence of exposition to oxygen}

The influence of a reduced oxygen concentration was investigated by lowering the oxygen exposure stepwise. Sample processing was separated into three steps: (1) dilution process, (2) pre-incubation of the microtiter plates, and (3) growth. As standard condition and as control, all three steps were performed under completely oxic conditions. In the experiment, three consecutive treatments were applied: (a) only an anoxic dilution series, (b) an anoxic dilution series and anoxic microtiter plates (to allow only for slow diffusion of oxygen into the inoculated plate) and (c) anoxic dilution series, anoxic microtiter plates and growth at $3 \% \mathrm{O}_{2}$. This experiment was repeated twice (7/10/99 and 24/11/99); in both cases, with a low $(0.06 \%)$ and a high $(3 \%)$ concentration of organic substrate.

Tubes for the "anoxic" dilution series were flushed with nitrogen for $30 \mathrm{~s}$. These tubes and the microtiter plates were pre-incubated in a desiccator for 1 week under nitrogen atmosphere with "Anaerocult A" reagents (Merck). The desiccator was flushed with nitrogen every 2 days.

\subsection{Influence of oxygen and substrate concentration}

Three levels of oxygen and substrate were chosen to test for their mutual influence on the cell counts. Oxygen levels were $3.4 \pm 1.0 \% ; 12.3 \pm 1.7 \%$ and $21.3 \pm 1.3 \%$; substrate concentrations were $0.006 \%$, $0.06 \%$ and $0.6 \%(\mathrm{w} / \mathrm{v})$. Desiccators as incubation vessels were evacuated and flushed with nitrogen (three times). After the fourth evacuation, pure oxygen was added and the rest filled up with nitrogen. The accuracy of the gas mixtures was verified with a gas chromatograph with thermal conductivity detector, and the mixture was renewed every week. The desiccator with $21 \%$ oxygen was equivalent to normal air, but it was set up the same way as the other mixtures. Plates were pre-incubated for 1 week to assure that the medium in the plates was in equilibrium with the respective gas phase. After inoculation, plates were covered with sterile plate sealers (Dynex Technologies) to avoid contamination and to reduce evaporation.

Nitrogen and oxygen gases were obtained from Messer-Griesheim at a purity of 5.0 and at technical grade.

\subsection{Influence of $N$-acyl homoserine lactones ( $A H L)$}

A mixture of the commercially available (Sigma) AHL butyryl-HL, hexanoyl-HL, heptanoyl-HL, octanoyl-HL and tetradecanoyl-HL dissolved in either acetonitrile or ethylacetate was prepared and diluted to yield an aqueous stock solution containing each AHL at $20 \mu \mathrm{M}$ concentration. This AHL mixture was added to microtiter plates to a final concentration of $0.9 \mu \mathrm{M}$ each. To test the influence of the solvents, control microtiter plates were set up containing the solvents at the same concentration $[0.0005 \%(\mathrm{v} / \mathrm{v})]$, without AHL; $0.06 \%$ nutrient broth plus yeast extract served as substrate.

\subsection{Comparison between viable and total bacterial counts}

Total bacterial counts (TBC) in water samples were determined with a Zeiss Axiophot microscope after DAPI staining (Turley, 1993). The TBC ob- 
tained at every sampling date $(=100 \%)$ was compared to the maximal viable counts obtained with the MPN technique. This relation was termed "cultivability".

\section{Results}

\subsection{Validation of MPN determination in microtiter plates}

To investigate the influence of different incubation conditions on the number of cultivated bacteria, a cultivation system had to be established, which allowed the comparison of numerous settings with high statistical confidence. We used the MPN technique in microtiter plates. These plates allow to run numerous parallels and dilution steps, thus increasing the statistical reliability of the data. The microtiter plates are easy to measure with a plate reader, and data processing can be automated.

Preliminary tests showed that the same cell numbers were obtained with plates incubated in a desiccator (evacuated and flushed with gas) as under plain air, and with or without plate sealers.

The threshold for differentiation between positive and negative wells (with $0.06 \%$ organic substrate) was examined with protein measurements. Highest negative dilutions had protein concentrations of 0.04 $\pm 0.01 \mathrm{mg} \mathrm{ml}^{-1},(n=5)$. "Negative" wells succeeding positive ones showed protein concentrations of $0.07 \pm 0.05 \mathrm{mg} \mathrm{ml}^{-1}(n=12)$ and "positive" wells had a protein concentration of $0.21 \pm 0.05 \mathrm{mg} \mathrm{ml}^{-1}$, $(n=17)$. This demonstrates that "positive" wells were indeed grown with bacteria, while "negative" wells were not always sterile, or faint growth was not detected. Thus, our method to evaluate positive and negative wells by a 1.5 times increase of optical density over the pure medium was sometimes too strict, causing perhaps still an underestimation of MPNs. Other authors increased the resolution sensitivity by staining plus microscopic counting of the high-dilution wells (Bianchi and Giuliano, 1996), but they also admit that this method is too expensive and time-consuming for routine use.

To test whether bacteria enumerated with liquid medium (the MPNs) are comparable with bacteria obtained on the commonly used agar-plates, the con- tent of highly diluted, positive and negative wells from microtiter plates was subcultured on solid media with CPS agar ( $0.25 \%$ of organic substrate) (Jones, 1970). At low substrate concentration $(0.06 \%)$, there was no significant relationship between the variables" "growth in liquid medium" and "growth on CPS agar plates" (contingency table analysis, $\mathrm{Chi}^{2}=3.6, p=0.06, n=18$ ). Two out of nine negative MPN wells grew on agar plates and three out of nine positive MPN-wells did not grow on agar plates. At high substrate concentration $(0.6 \%)$, there was a significant relationship between the variables" "growth in liquid medium" and "growth on CPS agar plates" (contingency table analysis, $\left.\mathrm{Chi}^{2}=6.5, p=0.01, n=15\right)$. The content of negative wells of the MPN never grew on the agar plates $(n=9)$ and the content of positive wells mostly grew on agar plate (five out of nine). Apparently, bacteria cultivated with low substrate concentration $(0.06 \%)$ were not able to form colonies on solid agar and were different from those cultivable on standard solid agar plates, whereas bacteria cultivated in liquid medium with higher substrate concentration $(0.6 \%)$ appeared to be similar to those growing on CPS agar plates.

Direct comparison of the viable counts obtained with the MPN technique and with agar plates revealed no significant differences. On one sampling date, MPNs were higher than counts obtained with agar plates; on two other sampling dates, identical numbers of bacteria were counted.

In order to optimise the recovery of bacteria from freshwater, different constituents of commonly used media were tested for their effect on the cultivability. Initial experiments showed that HEPES buffer (compared to TES, MOPS, and phosphate buffer, all 0.01 M) and an incubation temperature of $16{ }^{\circ} \mathrm{C}$ (ranging from $10,16,20$ to $30{ }^{\circ} \mathrm{C}$ ) yielded maximal MPNs. The concentration of inorganic phosphate (15-1500 $\mu \mathrm{M})$ had no influence on the MPN. Also, addition of glucose or acetate $(3-40 \mathrm{mM})$, alone or in addition to nutrient broth plus yeast extract, did not increase the MPNs (results not shown).

\subsection{Influence of substrate concentration}

Different concentrations of organic substrate were compared for their effect on cultivability of freshwa- 
ter bacteria. The applied substrate concentrations ranged from $0.0003 \%$ to $3 \%(\mathrm{w} / \mathrm{v})$ nutrient broth plus yeast extract. To compare the different sampling dates, all MPNs of one sampling date were related to $0.06 \%$ organic substrate (MPN at $0.06 \%=1$ ). There was a significant relationship between the relative MPNs and the logarithm of the substrate concentration. This influence was not linear, but more in the nature of a bell-shaped curve (Fig. 1), which could be described best by a polynomial regression of second order $\left(p<0.0001 ; r^{2}=0.56 ; n=45\right)$, i.e. $56 \%$ of the variability of the relative MPNs could be explained with the variable "substrate concentration". Highest numbers were obtained with substrate concentrations between $0.03 \%$ and $0.06 \%$. Both higher and lower substrate concentrations resulted in lower numbers (Fig. 1).

\subsection{Influence of exposition to oxygen}

The influence of exposition to oxygen before growth on the final number of planktonic bacteria was investigated twice $(7 / 10 / 99 ; 24 / 11 / 99)$. Since bacteria growing with low or high substrate concentrations might express different sensitivities to oxygen, two concentrations of organic substrate $(0.06 \%$, $3 \%)$ were applied. For better comparison of the two experiments, the MPN obtained in the completely oxic setting was set as $100 \%$. At low substrate concentrations $(0.06 \%)$, a completely oxic treatment of the samples yielded significantly higher cell counts

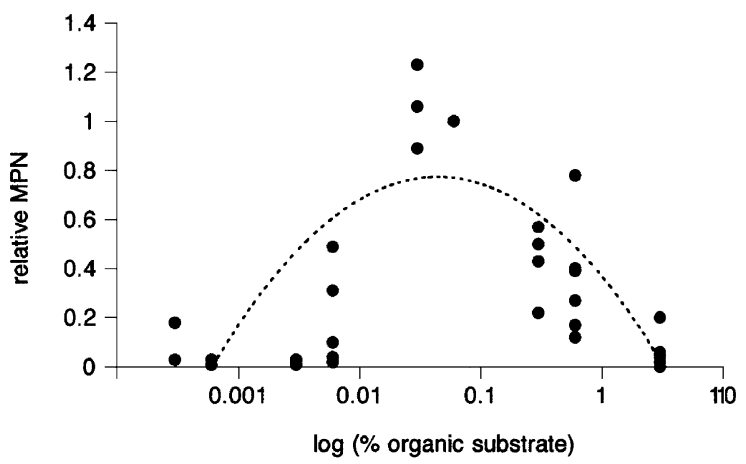

Fig. 1. Influence of substrate concentration (nutrient broth plus yeast extract, \% w/v) on the "most probable number" (MPN), with the MPN at $0.06 \%$ substrate set as "1". A polynome of second order described this relationship best $\left(p<0.0001 ; r^{2}=\right.$ $0.56 ; n=45)$.
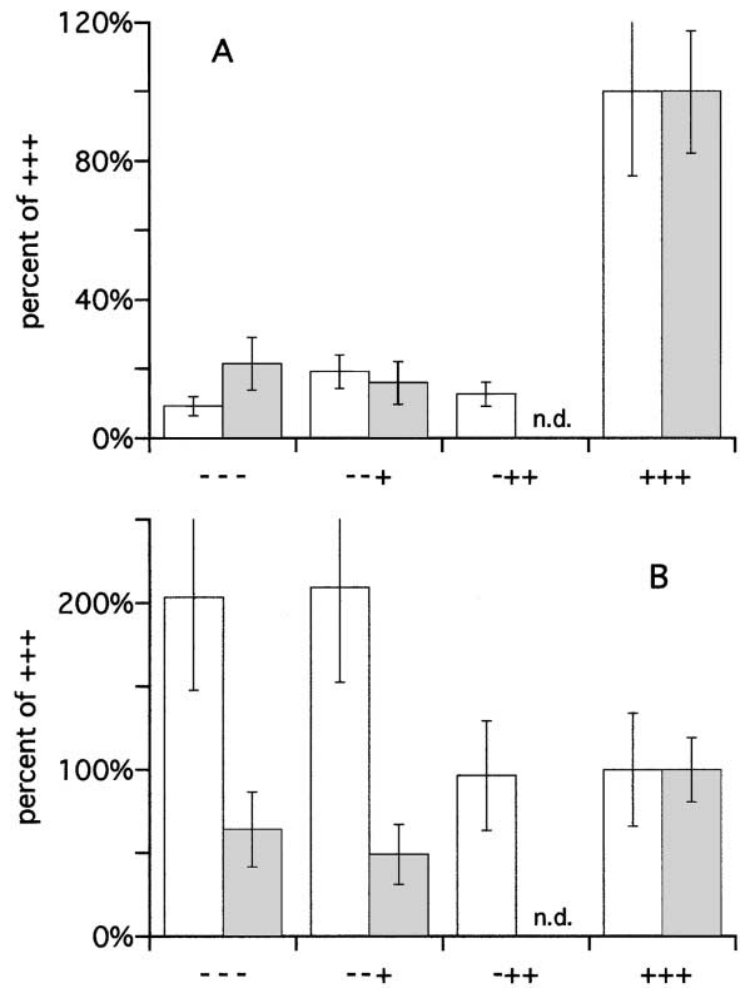

Fig. 2. Comparison between the percentage of "most probable number" ( = MPN) obtained with an oxic treatment of the sample $(+++=100 \%)$ and with reduced oxygen exposure during sample processing: " -++ " anoxic handling during the dilution process, "- -+ " anoxic handling during the dilution process and anoxic microtiter plates, " - - - " anoxic handling during the dilution process, anoxic microtiter plates and growth at $3 \% \mathrm{O}_{2}$. This experiment was done with $0.06 \%$ (A) and $3 \%$ (B) organic substrate and repeated twice [7/10/1999 ( $\square$ ) and 24/11/1999 ( $\square$ ]. Error bars indicate the standard error of the MPN calculation; n.d. $=$ not determined.

than any treatment applied to reduce the exposure to oxygen (anoxic handling during the dilution process, anoxic pre-incubation of plates or growth at $3 \% \mathrm{O}_{2}$, Fig. 2a). At high substrate concentrations (3\%), no significant differences between MPNs obtained under the different conditions could be detected (Fig. 2b).

\subsection{Influence of oxygen and substrate concentration}

In the following experiment, the effect of the oxygen concentration during growth at different con- 
centrations of organic substrate was investigated (Fig. $3)$. At low substrate concentrations $(0.006 \%)$, the MPNs were generally very low, ranging from no growth up to 45 cells $\mathrm{ml}^{-1}$, with maximal counts at $21 \% \mathrm{O}_{2}$. At $0.06 \%$ substrate concentration, the overall highest MPN of 245 cells ml ${ }^{-1}$ were obtained with $21 \% \quad \mathrm{O}_{2}$. At high substrate concentrations $(0.6 \%)$, the maximum MPN was also obtained with $21 \% \mathrm{O}_{2}\left(194\right.$ cells $\left.\mathrm{ml}^{-1}\right)$. Thus, with all substrate concentrations applied $(0.006 \%, 0.06 \%$ and $0.6 \%)$, the highest MPNs were recorded at $21 \% \mathrm{O}_{2}$. However, this was significant only for $0.06 \%$ substrate concentration; here, an oxygen atmosphere of $21 \%$ resulted in significantly higher MPNs than at $12 \%$ or $3 \% \mathrm{O}_{2}$ (unpaired $t$-test with rank-transformed MPNs, $n=17, p=0.02)$.

\subsection{Influence of $\mathrm{N}$-acyl homoserine lactones ( $A H L)$}

To test whether AHL might increase the number of viable counts, a mixture of five AHL differing in the length of the acyl side chain was added to medium with $0.06 \%$ organic substrate, and counts were compared to those obtained with the same medium without AHL $(=100 \%)$. This experiment was repeated three times $(05 / 07 / 00 ; 08 / 08 / 00$ and $16 / 08 / 00)$. At all sampling dates, the addition of AHL to the growth medium increased the number of heterotrophic bacteria to $127 \%, 140 \%$ and $141 \%$ of the standard medium (Fig. 4), even though these

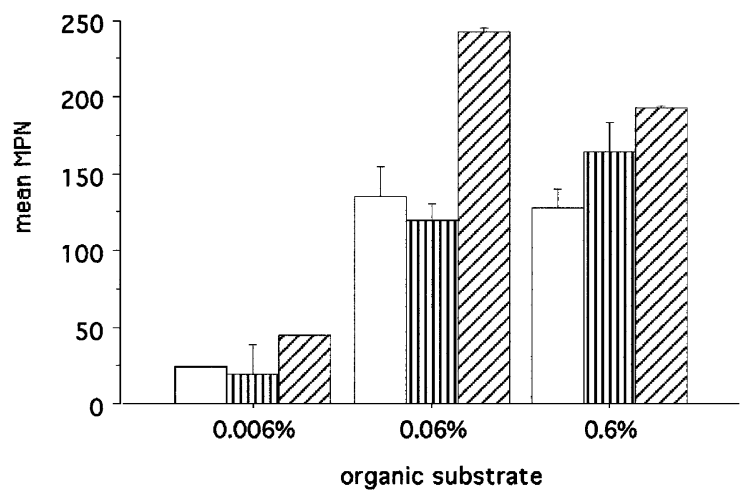

Fig. 3. The influence of oxygen on the "most probable number" (MPN) at different concentrations of organic substrate $(0.006 \%$,

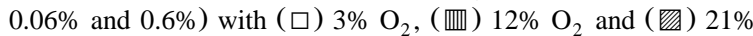
$\mathrm{O}_{2}$. Error bars indicate the standard error with $n=2$.

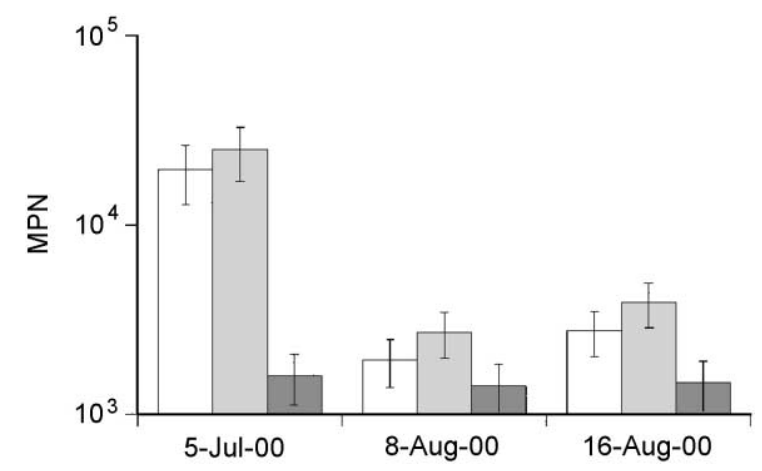

Fig. 4. The influence of a mixture of $N$-acyl homoserine lactones (AHL) ( $\square$ on the "most probable number" compared to a control without addition $(\square)$ and to a control $(\square)$ with only the organic solvents of the AHL solution added. This experiment was repeated three times on different sampling dates with $0.06 \%$ organic substrate concentration. Error bars indicate the standard error of the MPN calculation.

differences were not significant. Control microtiter plates showed that the AHL mixture was sterile and did not serve itself as a growth substrate. In further control plates containing the corresponding concentration of solvents (acetonitrile or ethylacetate) without AHL, less bacteria (45\%) were grown compared to the standard medium.

\subsection{Comparison between viable and total bacterial counts}

To check if the medium modifications really increased the cultivability, viable counts were compared to the total bacterial counts (TBC). During the investigation period, the TBC in Lake Constance water changed between $8.7 \times 10^{3}$ cells $\mathrm{ml}^{-1}$ in November 1999 and $2.2 \times 10^{5}$ cells ml ${ }^{-1}$ in August 1999. Secchi depths measured every other week were taken as estimates of primary productivity over the year (the water depths at which a white circular plate lowered into the water disappears is defined as the Secchi depth). TBC roughly followed the course of primary productivity in 1999 (Fig. 5a). High counts were obtained during the spring bloom and during the second bloom in summer/autumn. During the clearwater phase and in winter, the TBC decreased. Maximal MPN at each sampling date were compared with TBC. Overall, the cultivability 

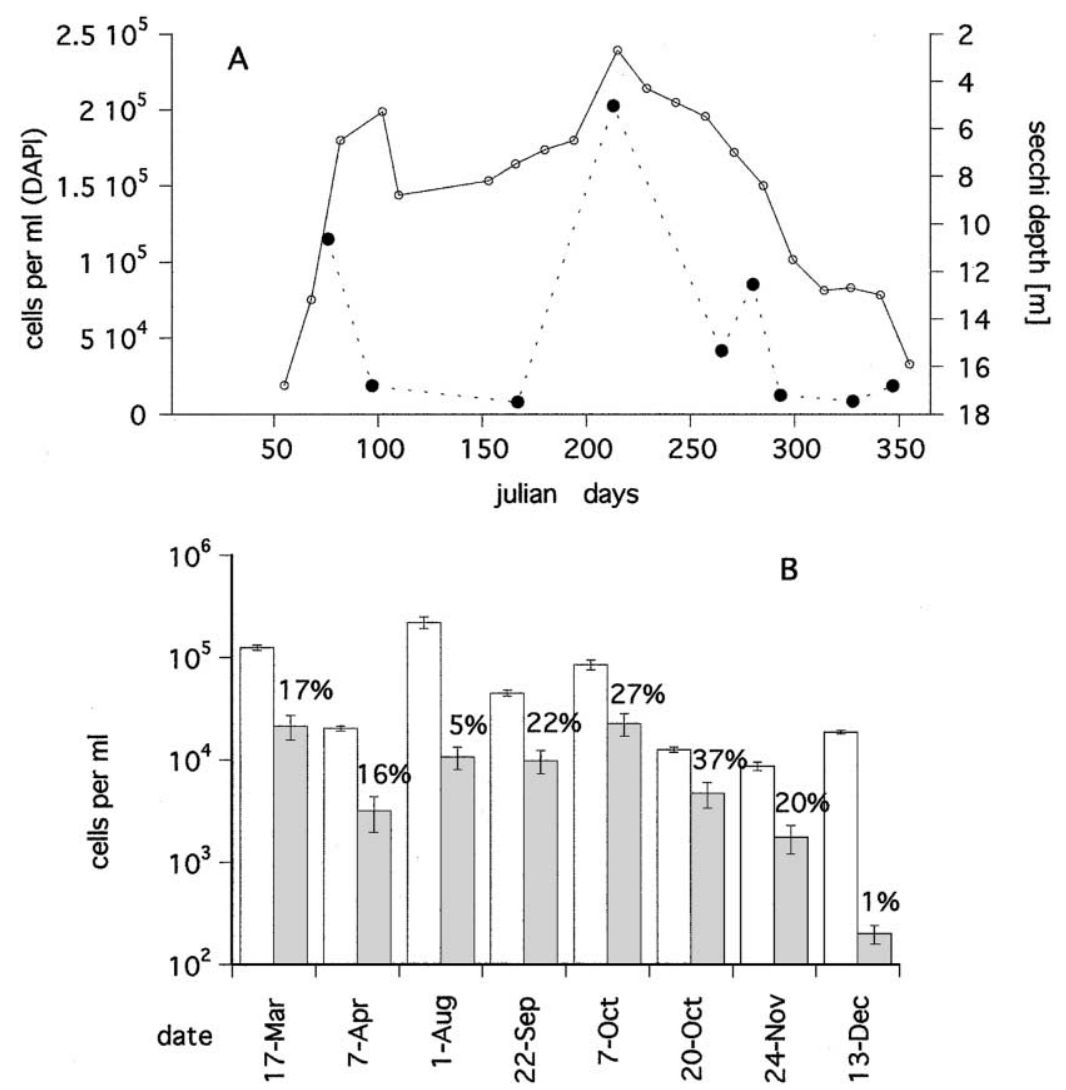

Fig. 5. (A) Secchi depth $(\bigcirc)$ and total bacterial counts after staining with DAPI $(O)$ in surface water of Lake Constance during the year 1999. (B) Total bacterial counts stained with DAPI ( $\square$ ) and the corresponding "most probable number" $\square$ ) with standard error. The cultivability is also indicated. (The water depths at which a white circular plate lowered into the water disappears is defined as the Secchi depth. The Secchi depth is taken as an estimate of primary productivity.)

ranged from $1 \%$ to $37 \%$. During the blooms in March and August, the cultivability (17\% and 5\%) did not differ substantially from that observed during the clearwater phase and in winter $(37 \%$ and $1 \%)$ (Fig. 5b).

\section{Discussion}

In order to obtain higher viable counts of heterotrophic planktonic bacteria, we varied the medium composition and incubation conditions. Surface water of Lake Constance was used to enumerate bacteria with the "most probable number" technique. The medium composition which yielded maximal viable counts was defined as the most suitable one and was compared to the TBC.

At least in oligotrophic environments, concentrations of organic carbon and substrate for heterotrophic bacteria are very low (1-2 mg DOC $\left.1^{-1}\right)$, and only $5-36 \%$ of this pool is considered labile (Weiss and Simon, 1999). Most bacteria appear to be well adapted to these low concentrations and to survive in a starvation state (Morita, 1997). However, commonly used media for cultivation (and enumeration) of heterotrophic bacteria from environmental samples apply much higher substrate concentrations (ca. $1.5 \mathrm{~g} \mathrm{C}^{-1}$ ) and consist of low molecular, labile compounds. Thus, we assumed that higher viable counts could be obtained by lowering the 
substrate (organic carbon) concentration, and thereby mimic the in situ conditions better.

In the present study we showed that there is a systematic correlation between viable counts of heterotrophs and the substrate concentration in the medium. For Lake Constance, we found optimal organic substrate concentrations of $0.03-0.06 \%$ $(\mathrm{w} / \mathrm{v})$, and significantly lower counts at higher and lower substrate concentrations.

Earlier observations already indicated that lowering the substrate content of an enumeration medium (0.2-0.1\%) leads to higher cell counts (Jones, 1970; Mikell et al., 1996), however, without showing a direct correlation. There are only few investigations on the influence of very low $(<0.06 \%)$ substrate concentrations on the counting efficiency. In Antarctic Ocean waters, more bacteria could be enumerated with media containing $0.06 \%$ substrate than with $0.00006 \%$ substrate (Tan et al., 1996). Our results imply that enumerations in oligotrophic environments with the commonly used media CPS, R2A, or the marine ZoBell medium with high concentrations of organic substrate $(0.25 \%, 0.3 \%$ and $0.6 \%$, respectively) (Reichardt, 1978) will necessarily yield only low counting recoveries. Whether this result obtained with water of oligotrophic Lake Constance can also be extrapolated to eutrophic lakes or sediments has to be further investigated.

Although the various complex media used differ in their composition, with tryptone, peptone, beef extract, or yeast extract as the most common ingredients, former studies have shown that the specific composition has only a minor influence on the number of viable heterotrophic bacteria (Jones, 1970). This was confirmed also in a recent, more refined study (Bartscht et al., 1999).

In this study, we could not find a deleterious effect of oxygen on bacterial growth, as reported by Olson et al. (2000) and Xenopoulos and Bird (1997). At low substrate concentrations, lowering the oxygen concentration always resulted in lower cell counts, whereas bacteria growing at high substrate concentrations were hardly influenced by the oxygen concentration. But since these bacteria occurred only in low numbers, it may be stated that the majority of bacteria that originate from oligotrophic surface waters is well adapted to the ambient oxygen concentration. This is supported by a study on groundwater bacteria; anoxic incubation recovered only $17 \%$ of the heterotrophic plate count obtained under oxic conditions (Shirey and Bissonnette, 1997).

Most bacteria in aquatic environments endure very low substrate concentration and are, therefore, thought to be mostly in a starvation phase (Morita, 1997). In Vibrio vulnificus, protective hydroperoxidase enzymes are induced during starvation, and only these pre-adapted cells can survive (Bloomfield et al., 1998). A sudden transfer of Escherichia coli, $V$. vulnificus or Micrococcus luteus cells to nutrient-rich agar at temperatures optimal for enzyme activity initiates an instantaneous production of superoxide and other radicals (Bloomfield et al., 1998). If such temperature or nutrient stress situations are avoided, the oxidative stress is easier to overcome. It is also open whether bacteria from an oligotrophic environment and cultivated at low organic substrate concentrations behave the same way as those ones used in most studies on the effect of hydrogen peroxide (Arana et al., 1992; Mizunoe et al., 1999).

Another aspect of bacterial physiology possibly influencing cultivability is intercellular communication by $\mathrm{N}$-acyl homoserine lactones (AHL) as extracellular signal molecules (Eberl, 1999). AHL might stimulate growth in multicellular aggregates (McLean et al., 1997), but would be diluted to ineffective concentrations in MPN assays. Therefore, addition of exogenous AHL might increase the viable counts, as we observed in our experiments. The observed trend is supported by the solvent control, which indicates an inhibiting effect of the solvents on growth. Although our knowledge on AHL-mediated quorum sensing phenomena in laboratory cultures is increasing, the ecological role of AHL is far from being understood (Eberl, 1999). One can speculate that AHL switch on specific genes necessary for growth, e.g. for siderophore production (Guan et al., 2000), for superoxide dismutase and catalase (Hassett et al., 1999), or for starvation survival (Thorne and Williams, 1999). Certainly, more detailed studies are required to elucidate the probably important ecological role of AHLs in the environment and their effect on cultivability.

Beyond the comparison of different medium composition with the subsequent MPNs, we also compared our viable counts with the total bacterial counts 
(TBC) obtained after DAPI staining. In general, our TBC values are lower than those described previously (Simon et al., 1998). This may be due to the fact that we sampled only the upper surface waters (ca. $10 \mathrm{~cm}$ ) and not those in 1-3-m depth. At this shallow depth, photo-inactivation may lead to lower cell numbers (Joux et al., 1999). The maximal MPN at each sampling date were related to the TBC. During and after phytoplankton blooms, we could not recover more bacteria than during winter when the substrate supply for heterotrophic bacteria should be short. Although the community structure of the bacterioplankton in Lake Constance varies with the season (Zwisler, 2000), for this study on the cultivability of bacterioplankton, we decided to neglect this aspect and calculated the average cultivability. The mean cultivability was $18 \pm 11 \%(n=8)$. Thus, our average cultivability was substantially higher than, e.g. $0.25 \%$ (Jones, 1977) or max. $7 \%$, as found in a recent, more refined study (Bartscht et al., 1999). In the oligotrophic marine environment, higher cultivabilities $(60 \%$ and $100 \%)$ could be obtained only by a very sensitive assessment of growth at very low substrate concentrations (i.e. the natural organic substrate content of sterile seawater) (Bianchi and Giuliano, 1996; Button et al., 1993).

In the present study, we increased the cultivability of bacteria in lake water samples mainly by decreasing the substrate concentration in the medium. Nonetheless, there is still a gap to close between our $18 \%$ and the theoretical $100 \%$. The "most probable number" method relies on the assumption that every single cell will grow (Cochran, 1950) and, consequently, cause a detectable turbidity increase. Staining and microscopic counting of high-dilution wells could increase the sensitivity and consequently the cultivability (Bianchi and Giuliano, 1996). On the other hand, the TBC (generally set as 100\%) obtained by staining probably has to be considered critical as well. Some studies propose that DAPI and acridine orange staining techniques overestimate the bacterioplankton abundance (Catala et al., 1999; Pinhassi et al., 1997). Thus, by correcting the bacterioplankton abundance, the cultivability of heterotrophic bacteria would increase accordingly. However, additional improvements of the medium to cultivate the majority of freshwater bacteria are still needed. Some aspects have been investigated in this study; others, such as a more thorough study on the influence of AHLs, factors stimulating the resuscitation of dormant cells or to substitute the undefined complex media still need to be taken into account.

\section{Acknowledgements}

Data on the Secchi depth were kindly provided by G. Richter of the Limnological Institute. This study was supported by the Deutsche Forschungsgemeinschaft (SFB 454), research funds of the Universität Konstanz, and the Fonds der Chemischen Industrie, Frankfurt/M.

\section{References}

Amann, R.I., Ludwig, W., Schleifer, K.-H., 1995. Phylogenetic identification and in situ detection of individual microbial cells without cultivation. Microbiol. Rev. 59 (1), 143-169.

Arana, I., Muela, A., Iriberri, J., Egea, L., Barcina, I., 1992. Role of hydrogen peroxide in loss of culturability mediated by visible light in Escherichia coli in a freshwater ecosystem. Appl. Environ. Microbiol. 58 (12), 3903-3907.

Bartscht, K., Cyprionka, H., Overmann, J., 1999. Evaluation of cell activity and of methods for the cultivation of bacteria from a natural lake community. FEMS Microbiol. Ecol. 28, 249-259.

Bernard, L., Schäfer, H., Joux, F., Courties, C., Muyzer, G., Lebaron, P., 2000. Genetic diversity of total, active and culturable marine bacteria in coastal seawater. Aquat. Microb. Ecol. 23, $1-11$.

Bianchi, A., Giuliano, L., 1996. Enumeration of viable bacteria in the marine pelagic environment. Appl. Environ. Microbiol. 62 (1), 174-177.

Bloomfield, S.F., Stewart, G.S.A.B., Dodd, C.E.R., Booth, I.R., Power, E.G.M., 1998. The viable but non-culturable phenomenon explained? Microbiology 144, 1-3.

Button, D.K., Schuts, F., Quang, P., Martin, R., Robertson, B.R., 1993. Viability and isolation of marine bacteria by dilution culture: theory, procedures, and initial results. Appl. Environ. Microbiol. 59 (3), 881-891.

Catala, P., Parhuisot, N., Bernard, L., Baudart, J., Lemarchand, K., Lebaron, P., 1999. Effectiveness of CSE to counterstain particles and dead bacterial cells with permeabilised membranes: application to viability assessment in waters. FEMS Microbiol. Lett. 178, 219-226.

Cochran, W.G., 1950. Estimation of bacterial densities by means of the "Most Probable Number". Biometrics 105-116.

Eberl, L., 1999. $\mathrm{N}$-acyl homoserinelactone-mediated gene regulation in Gram-negative bacteria. Syst. Appl. Microbiol. 22, 493-506. 
Guan, L.L., Onuki, H., Kamino, K., 2000. Bacterial growth stimulation with exogenous siderophore and synthetic $N$-Acyl homoserine lactone autoinducers under iron-limited and lownutrient conditions. Appl. Environ. Microbiol. 66 (7), $2797-$ 2803.

Hassett, D.J., Ma, J.F., Elkins, J.G., McDermott, T.R., Ochsner, U.A., West, S.H.E., Huang, C.T., Fredericks, J., Burnett, S., Stewart, P.S., McFeters, G., Passador, L., Iglewski, B.H., 1999. Quorum sensing in Pseudomonas aeruginosa controls expression of catalase and superoxide dismutase and mediates biofilm susceptibility to hydrogen peroxide. Mol. Microbiol. 34, 1082-1093.

Jones, J.G., 1970. Studies on freshwater bacteria: effect of medium composition and method on estimates of bacterial population. J. Appl. Bacteriol. 33, 679-686.

Jones, J.G., 1977. The effect of environmental factors on estimated viable and total population of planktonic bacteria in lakes and experimental enclosures. Freshwater Biol. 7, 67-91.

Joux, F., Jeffrey, W.H., Lebaron, P., Mitchell, D.L., 1999. Marine bacterial isolates display diverse responses to UV-B radiation. Appl. Environ. Microbiol. 65 (9), 3820-3827.

McDougald, D., Rice, S.A., Weichard, D., Kjelleberg, S., 1998. Nonculturability: adaptation or debilitation? FEMS Microbiol. Ecol. 25, 1-9.

McLean, R.J.C., Whiteley, M., Stickler, D.J., Fuqua, W., 1997. Evidence of autoinducer activity in naturally occurring biofilms. FEMS Microbiol. Lett. 154 (2), 259-263.

Mikell, A.T., Smith, C.L., Richardson, J.C., 1996. Evaluation of media and techniques to enumerate heterotrophic microbes from karst and sand aquifer springs. Microb. Ecol. 31 (2), $115-124$.

Mizunoe, Y., Wai, S.N., Takade, A., Yoshida, S., 1999. Restoration of culturability of starvation-stressed and low-temperature stressed Escherichia coli 0157 cells by using $\mathrm{H}_{2} \mathrm{O}_{2}$-degrading compounds. Arch. Microbiol. 172, 63-67.

Morita, R.Y., 1997. Bacteria in Oligotrophic Environments, Starvation-Survival Life Style. Chapman \& Hall, London, pp. 257-258.

Olson, J.B., Lord, C.C., McCarthy, P.J., 2000. Improved recoverability of microbial colonies from marine sponge samples. Microb. Ecol. 40, 139-147.

Pernthaler, J., Glöckner, F.-O., Unterholzner, S., Alfreider, A., Psenner, R., Amann, R., 1998. Seasonal community and population dynamics of pelagic bacteria and archaea in a high mountain lake. Appl. Environ. Microbiol. 64, 4299-4306.

Pinhassi, J., Zweifel, U.L., Hagström, A., 1997. Dominant marine bacterioplankton species found among colony-forming bacteria. Appl. Environ. Microbiol. 63 (9), 3359-3366.
Reichardt, W.T., 1978. Einführung in die Methoden der Gewässermikrobiologie. Gustav-Fischer Verlag, Stuttgart.

Russek, E., Colwell, R., 1983. Computation of most probable numbers. Appl. Environ. Microbiol. 45 (5), 1646-1650.

Shirey, J.J., Bissonnette, G.K., 1997. Recovery of coliform bacteria from rural groundwater supplies using reduced oxygen concentrations during incubation. Can. J. Microbiol. 43 (6), 583.

Simon, M., Tilzer, M.M., Müller, H., 1998. Bacterioplankton dynamics in a large mesotrophic lake: I. abundance, production and growth control. Arch. Hydrobiol. Ergeb. Limnol. 143 (3), 385-407.

Stabel, H.-H., 1998. Chemical composition and drinking water quality of the water from Lake Constance. Arch. Hydrobiol. Spec. Issues Adv. Limnol. 53, 13-30.

Tan, T.L., Reinke, M., Rüger, H.-J., 1996. New dilution method in microtiter-plates for enumeration and enrichment of copiotrophic and oligotrophic bacteria. Arch. Hydrobiol. 137 (4), 511-521.

Thorne, S.H., Williams, H.D., 1999. Cell density-dependent starvation survival of Rhizobium leguminosarum bv phaesoli: identification of the role of an $\mathrm{N}$-acyl homoserine lactone in adaptation to stationery-phase survival. J. Bacteriol. 181, 981990.

Turley, C.M., 1993. Direct estimates of bacterial numbers in seawater samples without incurring cell loss due to sample storage. In: Kemp, P.F., Sherr, B.F., Sherr, E.B., Cole, J.J. (Eds.), Handbook of Methods in Aquatic Microbial Ecology. Lewis Publishers, Boca Raton, FL, pp. 143-147.

Weinbauer, M.G., Beckmann, C., Höfle, M.G., 1998. Utility of green fluorescent nucleic acid dyes and aluminium oxide membrane filters for rapid epifluorescence enumeration of soil and sediment bacteria. Appl. Environ. Microbiol. 64 (12), 5000-5003.

Weiss, M., Simon, M., 1999. Consumption of labile dissolved organic matter by limnetic bacterioplankton: the relative significance of amino acids and carbohydrates. Aquat. Microb. Ecol. 17 (1), 1-12.

Widdel, F., Kohring, G.W., Mayer, F., 1983. Studies in dissimilatory sulfate-reducing bacteria that decompose fatty acids. III Characterization of the filamentous gliding Desulfonema limicola gen. nov. sp. nov. Arch. Microbiol. 134, 286-294.

Xenopoulos, M.A., Bird, D.F., 1997. Effect of acute exposure to hydrogen peroxide on the production of phytoplankton and bacterioplankton in a mesohumic Lake. Photochem. Photobiol. 66 (4), 471-478.

Zwisler, W., 2000. Strukturanalyse planktischer Bakteriengemeinschaften. PhD thesis, University of Oldenburg. 